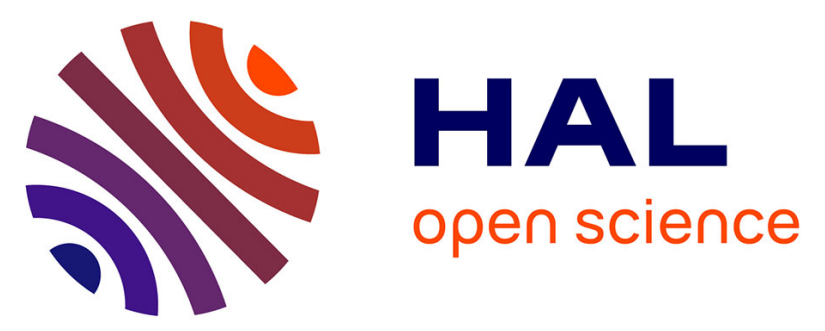

\title{
High Catalytic Activity of Heterometallic (Fe6Na7 and Fe6Na6) Cage Silsesquioxanes in Oxidations with Peroxides
}

Alexey Yalymov, Alexey Bilyachenko, Mikhail Levitsky, Alexander Korlyukov, Victor N. Khrustalev, Lidia Shul'pina, Pavel V. Dorovatovskii, Marina Es'kova, Frédéric Lamaty, Xavier Bantreil, et al.

\section{To cite this version:}

Alexey Yalymov, Alexey Bilyachenko, Mikhail Levitsky, Alexander Korlyukov, Victor N. Khrustalev, et al.. High Catalytic Activity of Heterometallic (Fe6Na7 and Fe6Na6) Cage Silsesquioxanes in Oxidations with Peroxides. Catalysts, 2017, 7 (12), pp.101. 10.3390/catal7040101 . hal-02385335

\section{HAL Id: hal-02385335 https://hal.science/hal-02385335}

Submitted on 28 Nov 2019

HAL is a multi-disciplinary open access archive for the deposit and dissemination of scientific research documents, whether they are published or not. The documents may come from teaching and research institutions in France or abroad, or from public or private research centers.
L'archive ouverte pluridisciplinaire HAL, est destinée au dépôt et à la diffusion de documents scientifiques de niveau recherche, publiés ou non, émanant des établissements d'enseignement et de recherche français ou étrangers, des laboratoires publics ou privés. 
Article

\title{
High Catalytic Activity of Heterometallic $\left(\mathrm{Fe}_{6} \mathrm{Na}_{7}\right.$ and $\left.\mathrm{Fe}_{6} \mathrm{Na}_{6}\right)$ Cage Silsesquioxanes in Oxidations with Peroxides
}

\author{
Alexey I. Yalymov ${ }^{1}$, Alexey N. Bilyachenko ${ }^{1,2, *}$, Mikhail M. Levitsky ${ }^{1}$,

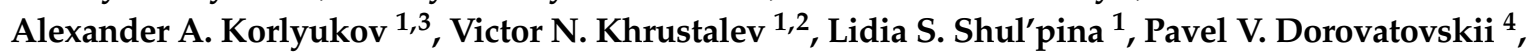 \\ Marina A. Es'kova ${ }^{1}$, Frédéric Lamaty ${ }^{5, *}$, Xavier Bantreil ${ }^{5}$, Benoît Villemejeanne ${ }^{5}$, \\ Jean Martinez ${ }^{5}$, Elena S. Shubina ${ }^{1}$, Yuriy N. Kozlov ${ }^{6,7}$ and Georgiy B. Shul'pin ${ }^{6,7, *}$ \\ 1 A. N. Nesmeyanov Institute of Organoelement Compounds, Russian Academy of Sciences, Vavilov Str., 28, \\ Moscow 119991, Russia; alexyalymov@gmail.com (A.I.Y.); levitsk@ineos.ac.ru (M.M.L.); \\ alex@xrlab.ineos.ac.ru (A.A.K.); vnkhrustalev@gmail.com (V.N.K.); shulpina@ineos.ac.ru (L.S.S.); \\ marinaeskovskaya@gmail.com (M.A.E.); shu@ineos.ac.ru (E.S.S.) \\ 2 Inorganic Chemistry Department, People's Friendship University of Russia (RUDN University), \\ Miklukho-Maklay Str., 6, Moscow 117198, Russia \\ 3 Chemistry department, Therapeutic faculty, Pirogov Russian National Research Medical University, \\ Ostrovitianov Str., 1, Moscow 117997, Russia \\ 4 National Research Center "Kurchatov Institute", Akademika Kurchatova pl., 1, Moscow 123182, Russia; \\ paulgemini@mail.ru \\ 5 Institut des Biomolécules Max Mousseron (IBMM) UMR 5247, CNRS, Université de Montpellier, ENSCM, \\ Université de Montpellier Campus Triolet Place Eugène Bataillon, Montpellier CEDEX 5, 34095, France; \\ xavier.bantreil@umontpellier.fr (X.B.); benoit.villemejeanne@enscm.fr (B.V.); martinez@univ-montp1.fr (J.M.) \\ 6 Semenov Institute of Chemical Physics, Russian Academy of Sciences, Ulitsa Kosygina, dom 4, \\ Moscow 119991, Russia; yunkoz@mail.ru \\ 7 Chair of Chemistry and Physics, Plekhanov Russian University of Economics, Stremyannyi pereulok, \\ dom 36, Moscow 117997, Russia \\ * Correspondence: bilyachenko@ineos.ac.ru (A.N.B.); frederic.lamaty@umontpellier.fr (F.L.); \\ shulpin@chph.ras.ru (G.B.S.); Tel.: +7-499-135-9369 (A.N.B.); +33-4-6714-3847 (F.L.); +7-495-939-7317 (G.B.S.)
}

Academic Editor: Kei Manabe

Received: 16 February 2017; Accepted: 21 March 2017; Published: 27 March 2017

\begin{abstract}
Two types of heterometallic (Fe(III),Na) silsesquioxanes- $\left[\mathrm{Ph}_{5} \mathrm{Si}_{5} \mathrm{O}_{10}\right]_{2}\left[\mathrm{Ph}_{10} \mathrm{Si}_{10} \mathrm{O}_{21}\right] \mathrm{Fe}_{6}\left(\mathrm{O}^{2-}\right)_{2} \mathrm{Na}_{7}$ $\left(\mathrm{H}_{3} \mathrm{O}^{+}\right)(\mathrm{MeOH})_{2}(\mathrm{MeCN})_{4.5} \cdot 1.25(\mathrm{MeCN})$, I, and $\left[\mathrm{Ph}_{5} \mathrm{Si}_{5} \mathrm{O}_{10}\right]_{2}\left[\mathrm{Ph}_{4} \mathrm{Si}_{4} \mathrm{O}_{8}\right]_{2} \mathrm{Fe}_{6} \mathrm{Na}_{6}\left(\mathrm{O}^{2-}\right)_{3}(\mathrm{MeCN})_{8.5}\left(\mathrm{H}_{2} \mathrm{O}\right)_{8.44}$ ， II-were obtained and characterized. X-ray studies established distinctive structures of both products, with pair of $\mathrm{Fe}(\mathrm{III})-\mathrm{O}-$ based triangles surrounded by siloxanolate ligands, giving fascinating cage architectures. Complex II proved to be catalytically active in the formation of amides from alcohols and amines, and thus becoming a rare example of metallasilsesquioxanes performing homogeneous catalysis. Benzene, cyclohexane, and other alkanes, as well as alcohols, can be oxidized in acetonitrile solution to phenol—the corresponding alkyl hydroperoxides and ketones, respectively—by hydrogen peroxide in air in the presence of catalytic amounts of complex II and trifluoroacetic acid. Thus, the cyclohexane oxidation at $20^{\circ} \mathrm{C}$ gave oxygenates in very high yield of alkanes (48\% based on alkane). The kinetic behaviour of the system indicates that the mechanism includes the formation of hydroxyl radicals generated from hydrogen peroxide in its interaction with di-iron species. The latter are formed via monomerization of starting hexairon complex with further dimerization of the monomers.
\end{abstract}

Keywords: alkanes; amides; hydrogen peroxide; dinuclear complexes; iron complexes; metallasiloxanes 


\section{Introduction}

Heterometallic complexes and clusters are among the most popular objects of contemporary chemistry, due to several remarkable features. First of all, the use of different metal ions is known as a key to controlled design of high-nuclearity complexes of picturesque molecular architecture [1-5]. Also, acting together, different metal ions provide catalytic activity in a wide range of processes [6-8], as well as intriguing magnetic properties [9]. The most popular synthetic approaches to such complexes involve use of organic ligands as well as application of "complex-as-ligand" tactics [10-13].

In turn, high reactivity and flexibility of siloxane ligands allow us to evaluate them as promising potential components of heterometallic complexes. Indeed, several heterometallic metallasiloxanes of attractive cage-like molecular geometry were described [14-17]. Importantly, Fe-containing siloxanes may be regarded as the most attractive representatives of metallasiloxanes, being artificial models of catalytically prospective silicates, zeolites, and iron oxides. Surprisingly, such complexes are still scarce in literature [18]. In this context, we were interested in the synthesis of new types of (Fe, M) siloxane geometries. As a pair of metal ions, a Fe/Na combination has been chosen because of the following reasons. It is known that sodium containing heterometallic cage siloxanes provide exceptional varieties of architecture [14-17], as well as catalytic activities $[16,17,19,20]$ and magnetic (spin glass) properties [21-24]. It is explained by the participation of specific siloxanolate [RSi(O)ONa] ligand in cage construction, giving rise to multiple metallasiloxane architectures [17]. It is also noteworthy that several reports have discussed in detail the influence of reactants ratio and/or choice of solvent system on structural features of cage-like metallasilsesquioxanes [14-17,25-27]. This tactic has been rarely used for $\mathrm{Fe}$, Na-silsesquioxane design. Furthermore, a unique example of such architecture, namely $\mathrm{Fe}_{6} \mathrm{Na}_{8}$ compound featuring a Lantern shape, was synthesized as its butanol/toluene complex by some of us very recently [23]. The first results regarding the application of the approach "ratio/solvent choice" towards the synthesis of Fe, Na-silsesquioxanes are reported herein, along with catalytic studies of the obtained complex under oxidation and amidation conditions.

\section{Results and Discussion}

\subsection{Syntheses and Structures of Catalysts}

The synthesis of target Fe,Na-silsesquioxanes was performed by transformation of $\mathrm{PhSi}(\mathrm{OEt})_{3}$ into intermediate siloxanolate $\left[(\mathrm{PhSi}(\mathrm{O}) \mathrm{ONa})_{n}\right]$ species. Reactions of sodium siloxanolate with iron(III) chloride were carried out in various media (DMF, THF, DMSO, or 1,4-dioxane). All of these solvents already proved to be proper solvating ligands for metallasilsesquioxane design [14-17,25-28]. Despite our expectations, isolation of a crystalline product in these reactions failed. However, the use of acetonitrile as a medium for synthesis/crystallization led to the isolation of unusual $\mathrm{Fe}, \mathrm{Na}$-phenylsilsesquioxane $\left\{\left[\mathrm{Ph}_{5} \mathrm{Si}_{5} \mathrm{O}_{10}\right]_{2}\left[\mathrm{Ph}_{10} \mathrm{Si}_{10} \mathrm{O}_{21}\right] \mathrm{Fe}_{6}\left(\mathrm{O}^{2-}\right)_{2} \mathrm{Na}_{7}\left(\mathrm{H}_{3} \mathrm{O}^{+}\right)(\mathrm{MeOH})_{2}(\mathrm{MeCN})_{4.5}\right\} .1 .25(\mathrm{MeCN})$ I in $16 \%$ yield (Figure 1).

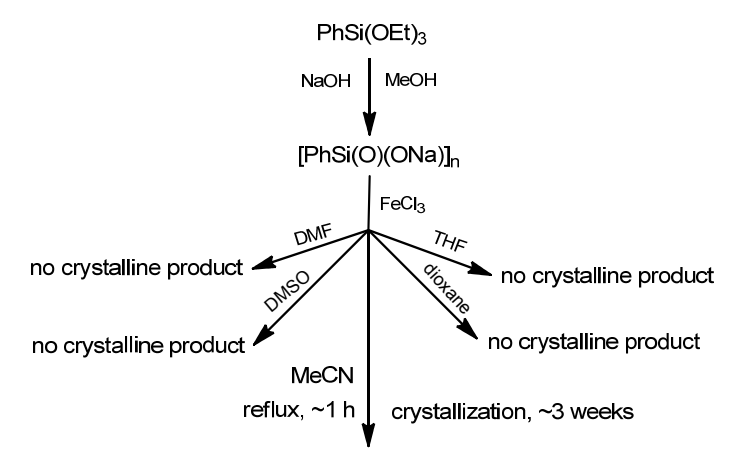

Figure 1. Scheme of solvent variation during synthesis of Fe,Na-phenylsilsesquioxanes. Use of MeCN provided $\mathbf{I}$. 
Taking this observation in mind, we focused on acetonitrile-containing media. Varying the ratio between reactants was found to be effective for changing the product framework. Formation of complex II (26\% yield, Figure 2$)$ was observed when a $1 / 1.4 / 0.33$ ratio between interacting silane $/ \mathrm{NaOH} / \mathrm{FeCl}_{3}$ was used; while in the synthesis of $\mathbf{I}$, ratio between reactants was $\sim 1 / 1 / 0.25$. The composition of product II differs from complex $\mathbf{I}$ and could be described as $\left[\mathrm{Ph}_{5} \mathrm{Si}_{5} \mathrm{O}_{10}\right]_{2}\left[\mathrm{Ph}_{4} \mathrm{Si}_{4} \mathrm{O}_{8}\right]_{2} \mathrm{Fe}_{6} \mathrm{Na}_{6}\left(\mathrm{O}^{2-}\right)_{3}(\mathrm{MeCN})_{8.5}\left(\mathrm{H}_{2} \mathrm{O}\right)_{8.44}$. Single crystal X-ray diffraction study revealed fascinating cage-like structures for both products (Figures 3 and 4).

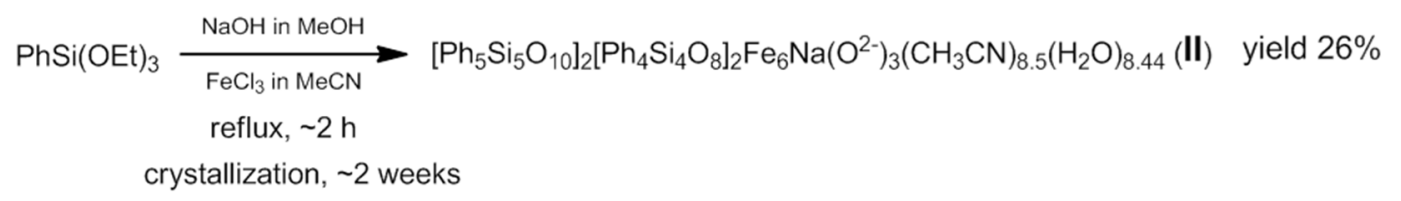

Figure 2. General scheme for the synthesis of II.
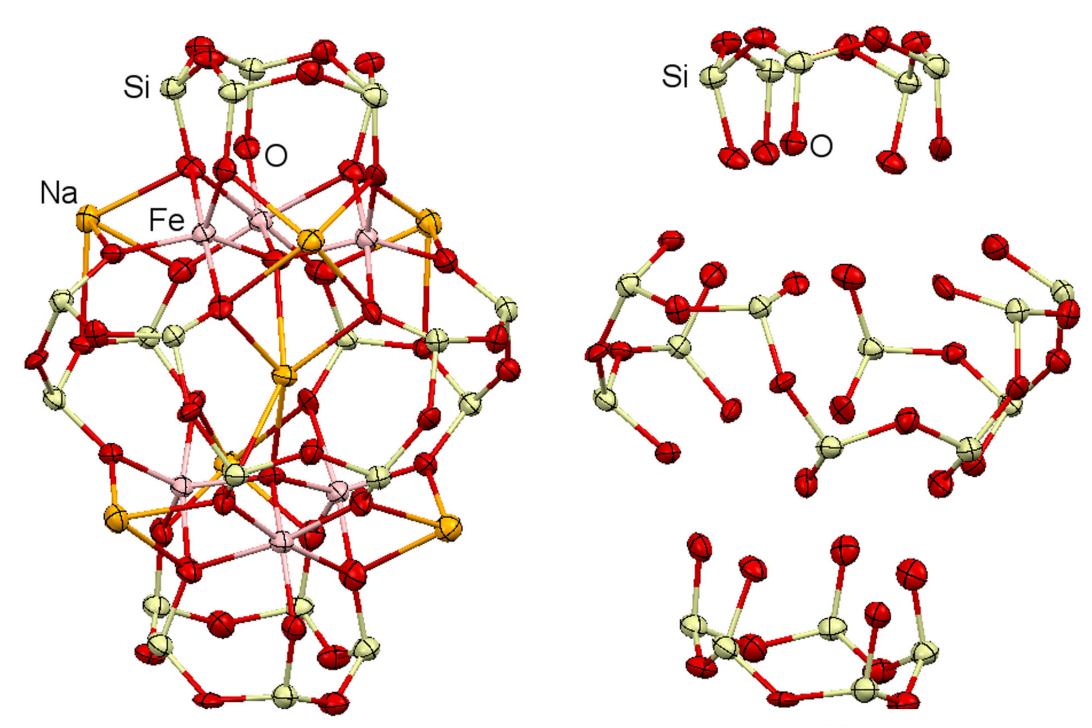

Figure 3. Molecular structures of $\left\{\left[\mathrm{Ph}_{5} \mathrm{Si}_{5} \mathrm{O}_{10}\right]_{2}\left[\mathrm{Ph}_{10} \mathrm{Si}_{10} \mathrm{O}_{21}\right] \mathrm{Fe}_{6}\left(\mathrm{O}^{2-}\right)_{2} \mathrm{Na}_{7}\left(\mathrm{H}_{3} \mathrm{O}^{+}\right)(\mathrm{MeOH})_{2}(\mathrm{MeCN})_{4.5}\right\}$. $1.25(\mathrm{MeCN}) \mathbf{I}(\mathbf{l e f t})$ and its silsesquioxane ligands (right).

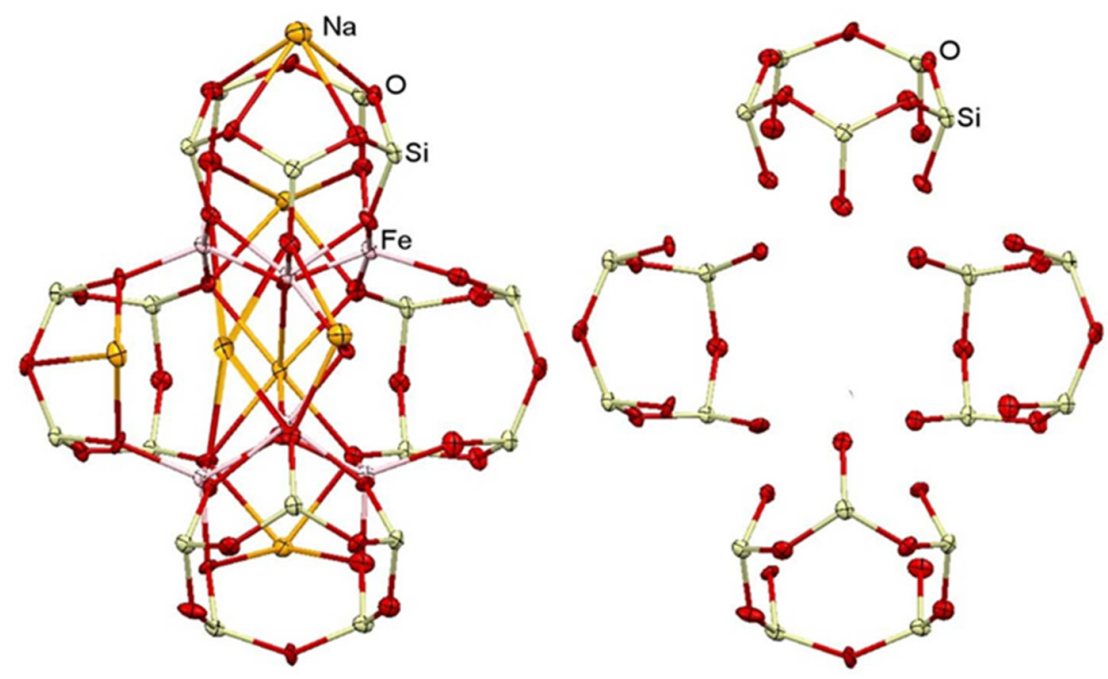

Figure 4. Molecular structures of $\left[\mathrm{Ph}_{5} \mathrm{Si}_{5} \mathrm{O}_{10}\right]_{2}\left[\mathrm{Ph}_{4} \mathrm{Si}_{4} \mathrm{O}_{8}\right]_{2} \mathrm{Fe}_{6} \mathrm{Na}_{6}\left(\mathrm{O}^{2-}\right)_{3}\left(\mathrm{CH}_{3} \mathrm{CN}\right)_{8.5}\left(\mathrm{H}_{2} \mathrm{O}\right)_{8.44}$ (II) (left) and its silsesquioxane ligands (right). 
The most attractive feature of compounds I and II is the nature of their silsesquioxane ligands. Compound $\mathbf{I}$ includes two five-membered cyclic ligands of composition $\left[\mathrm{Ph}_{5} \mathrm{Si}_{5} \mathrm{O}_{10}\right]$ and an acyclic ten-membered belt of composition $\left[\mathrm{Ph}_{10} \mathrm{Si}_{10} \mathrm{O}_{21}\right]$ (Figure 3 right). Symptomatically, the same combination of ligands was observed in a previously reported $\mathrm{Fe}_{6} \mathrm{Na}_{8}$ compound [23]. In turn, compound II includes only cyclic ligands, two four- and two five-membered ones, with compositions $\left[\mathrm{Ph}_{4} \mathrm{Si}_{4} \mathrm{O}_{8}\right]$ and $\left[\mathrm{Ph}_{5} \mathrm{Si}_{5} \mathrm{O}_{10}\right]$, respectively (Figure 4 right). The presence of four-membered cyclic ligand is an extremely rare feature for cage metallasilsesquioxanes. To the best of our knowledge, we could cite only di- and tetranuclear Ti(IV)-containing compounds, obtained from cyclotetrasiloxanetetraols [29]. Compound II is thus the first instance of the simultaneous presence of four- and five-membered cyclic ligands in a metallasilsesquioxane structure.

A common feature of complexes I and II is the presence of six iron(III) centers. These are combined into two trinuclear metal oxo clusters $\left[\mathrm{Fe}_{3} \mathrm{O}_{12}\right]^{15-}$, including two penta- and one hexacoordinated Fe(III) ions (Figure 5). The first observation of such clusters in metallasilsesquioxane structure was reported by some of us [23]. It is noteworthy that the locations of trinuclear units in cages of I and II are quite different. In the case of compound I, these clusters are "independent", connected through siloxane bonds (Figure 5), with the shortest contact between iron ions from different trinuclear units equal to $5.66 \AA$. On the other hand, trinuclear fragments of II are connected straight through bridging oxygen atoms (Figure 5), with the shortest Fe-Fe contact equal to $3.13 \AA$. In the case of compounds I and II, such rearrangement results in the formation of $\left[\mathrm{Fe}_{3} \mathrm{O}_{12}\right]^{15-}$ units; this is most probably explained by the high stability of such trinuclear geometry. To some extent, that statement could be confirmed by the observation of the same clusters in the composition of some other complexes [30-34].
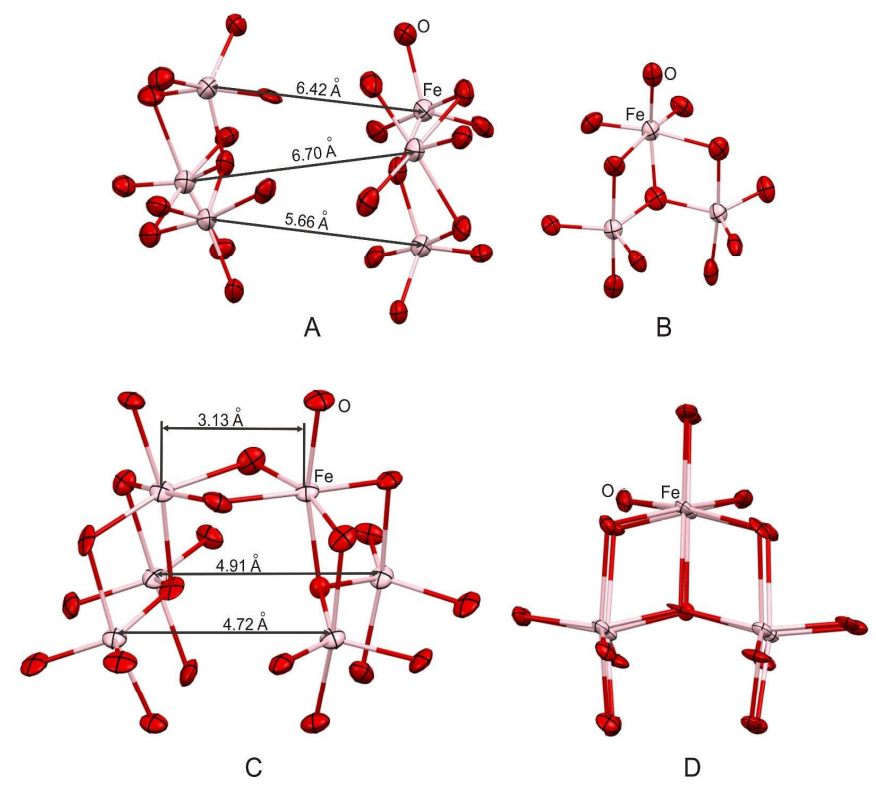

Figure 5. Pairs of trinuclear clusters in the frameworks of I (A) and II (C); General view of trinuclear iron oxo cluster in I (B) and II (D).

In our opinion, the appearance of such trinuclear $\left[\mathrm{Fe}_{3} \mathrm{O}_{12}\right]^{15-}$ clusters in the structures of $\mathbf{I}$ and II deserves additional discussion. Formal logic of metallasilsesquioxane synthesis implies formation of Si-O-M units by the reaction of silanolate Si-O-Na with metal chloride $\mathrm{M}-\mathrm{Cl}$ functional groups. Thus, formation of iron oxo M-O-M fragments could not be explained just by a reactants interaction. We suggest that such (M-O-M) structural units arise as a consequence of metallasilsesquioxane skeleton rearrangement in solution. Several examples of such processes for individual and oligomeric metallasilsesquioxanes have been summarized by some of us [35-37]. 
On the other hand, the $\left[\mathrm{Fe}_{x} \mathrm{O}_{y}\right]_{n}$ species could be formed in solution from $\mathrm{FeCl}_{3}$ and the base that is always present in such media $\left(\mathrm{OH}^{-}\right.$in equilibrium with $\left.\mathrm{OEt}^{-}\right)$. These ironoxo units might then be trapped by the siloxane species. It is clear that the mechanism of metallasilsesquioxane cage formation is still a questionable subject, and many factors-including the newest results on siloxanolate and silanols reactivity [38-40], as well as DFT estimated influence of solvents on CLMS formation [41]—should be taken in consideration.

\subsection{Catalytic Transformation of Alcohols and Amines into Amides}

Only isolated examples of copper and iron catalysis involving silsesquioxane complexes were already reported by ourselves [23,42] and others [43] in the literature. Complex II featuring an innovative structure was thus evaluated in the direct formation of amides from alcohols and amines. Thanks to the good solubility of II in organic solvent, stock solution could be prepared and allowed us to work at low iron loading. Reactions of benzyl alcohol with various ammonium chlorides were performed using as low as $500 \mathrm{ppm}$ of iron in the presence of tert-butylhydroperoxide (TBHP) as oxidant and calcium carbonate, in refluxing acetonitrile (Scheme 1). To our delight, primary and secondary amines reacted accordingly and corresponding amides could be obtained in yields up to $77 \%$ (compound 3e). Steric hindrance had a strong influence on the amidation reaction, since $\mathrm{N}$-tert-butyl benzamide $3 \mathrm{~d}$ was isolated in only $42 \%$ yield. Importantly, the turnover number (TON) and turnover frequency (TOF) values obtained herein-up to 1540 and $86 \mathrm{~h}^{-1}$, respectively-outmatched the values reported in the literature, with $\mathrm{FeCl}_{2} \cdot 4 \mathrm{H}_{2} \mathrm{O}$ in refluxing acetonitrile (TON $\leq 9$ and TOF $\leq 2.2 \mathrm{~h}^{-1}$ ) [44], or under microwave irradiation (TON $\leq 16.8$ and $\mathrm{TOF} \leq 33.6 \mathrm{~h}^{-1}$ ) [45].

Optimization of the reaction conditions was performed in a previous publication dealing with a different iron complex [23]. The conditions were thus directly adapted to this new complex, in order to allow comparison between the results obtained with two different complexes. The minimum amount of TBHP to obtain satisfactory results in terms of reaction time and yield is 4 equivalents. Since 2 equivalents are required for oxidation, the other 2 equivalents might decompose during the course of the reaction at $80^{\circ} \mathrm{C}$. In addition, since only $500 \mathrm{ppm}$ of iron are used, recyclability was not envisioned on this scale ( $0.5 \mathrm{mmol}$ of ammonium salt). Scaling-up of the reaction, in order to study the potential changes in structure of complex II during the catalytic cycle, as well as its recyclability, are currently ongoing in the laboratory.

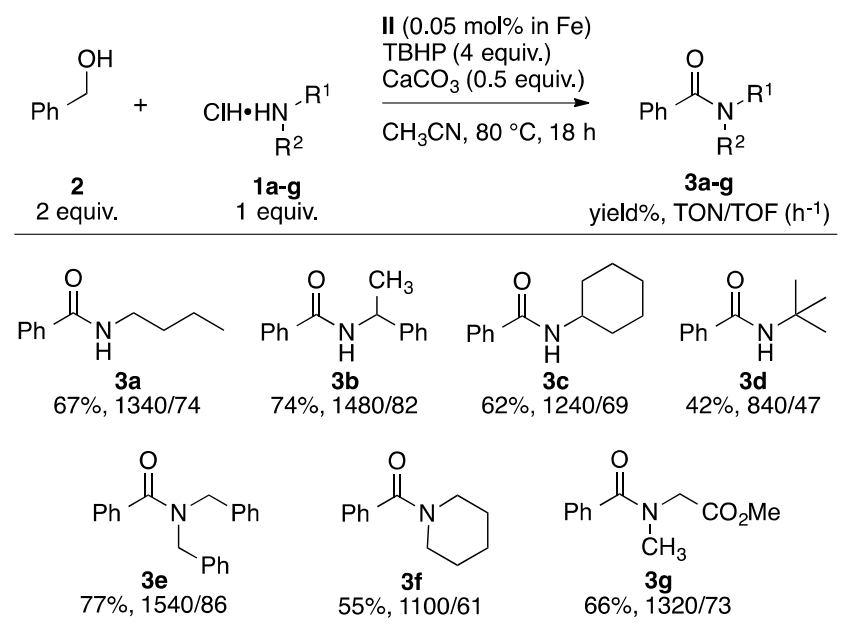

Scheme 1. Evaluation of complex II in amide bond formation. Turnover number $(\mathrm{TON})=(\mathrm{mmol}$ of product $) /(\mathrm{mmol}$ of $\mathrm{Fe})$. Turnover frequency $(\mathrm{TOF})=\mathrm{TON} /($ reaction time $)$, given in $\mathrm{h}^{-1}$. 


\subsection{Catalytic Oxidation of Alcohols and Hydrocarbons}

Even though several groups studied the iron-catalyzed oxidation of alcohols into amides, the precise mechanism is not yet completely elucidated. After oxidation of the alcohol into corresponding aldehyde, addition of the amine-generated in situ by reaction of the ammonium salt with poorly soluble calcium carbonate- onto the aldehyde and further oxidation of the hemiaminal would yield the desired amide. Due to the presence of iron and peroxide, it seems rather rational that radical species might be involved during the oxidation steps.

In turn, many mono or polynuclear iron-based compounds are known to be good catalysts for the oxidation of benzene, alcohols [46], and saturated and aromatic hydrocarbons [47-53] with peroxides. Oxygen-activating proteins, and especially enzymes containing polynuclear iron sites, attract a great deal of interest. Synthesized iron complexes are models of some enzymes with di-iron sites [54-56]. Methane monooxygenase (MMO) from methane-utilizing bacteria converts alkanes into the corresponding alcohols. Such enzymes oxidize regioselectively $n$-alkanes to afford predominately (in the case of $n$-heptane, even exclusively) 2 -alcohols [57]. Compound II containing a polynuclear iron complex with chelating oxo-ligands exhibits some features similar to that of binuclear alkane oxygenases, and thus can be considered as an "inorganic alkane oxygenase". In this context, behavior of compound II might be compared to our newest results concerning catalytic activity of Fe(III)-based silsesquioxane [23] and germaniumsesquioxane [58].

Complex II was found to be a very good catalyst in oxidations of alcohols, benzene, and alkanes with TBHP and $\mathrm{H}_{2} \mathrm{O}_{2}$. It is important to note that the reaction does not occur in the absence of trifluoroacetic acid. Gratifyingly, 1-phenylethanol and cyclooctanol could be converted into corresponding ketones in yields up to $92 \%$ and $85 \%$, respectively, with only $0.08 \mathrm{~mol} \%$ of catalyst II (Table 1).

Table 1. Oxidation of alcohols catalyzed by compound II.

\begin{tabular}{|c|c|c|c|c|}
\hline \multirow[b]{2}{*}{ Entry } & \multicolumn{3}{|c|}{$\begin{array}{l}\text { II }(0.08 \text { mol } \%) \\
\mathrm{H}_{2} \mathrm{O}_{2} \text { or TBHP } \\
\text { TFA }(8 \mathrm{~mol} \%)\end{array}$} & $\begin{array}{l}0 \\
1 \\
L^{\prime}\end{array}$ \\
\hline & Alcohol & Oxidant & Time (h) & Ketone Yield (\%) \\
\hline 1 & $\mathrm{OH}$ & $\mathrm{H}_{2} \mathrm{O}_{2}$ & 3 & 30 \\
\hline 2 & & & 5 & 50 \\
\hline 3 & & ТВНР & 4 & 80 \\
\hline 4 & & & 5 & 92 \\
\hline 5 & & TBHP & 3 & 71 \\
\hline 6 & & & 4 & 80 \\
\hline 7 & & & 5 & 85 \\
\hline
\end{tabular}

Reaction conditions: Alcohol $(0.6 \mathrm{M})$, oxidant (1.7 $\mathrm{M}$ for $\mathrm{H}_{2} \mathrm{O}_{2}$ or $1.5 \mathrm{M}$ for tert-butylhydroperoxide [TBHP]), $\mathrm{CF}_{3} \mathrm{COOH}(0.05 \mathrm{M})$, II $\left(5 \times 10^{-4} \mathrm{M}\right), \mathrm{CH}_{3} \mathrm{CN}, 40^{\circ} \mathrm{C}$ (entries 1,2$)$ or $50{ }^{\circ} \mathrm{C}$ (entries $\left.3-7\right)$.

The oxidation of benzene into phenol, utilizing $\mathrm{H}_{2} \mathrm{O}_{2}(50 \%)$ in the presence of compound II in catalytic amounts, was also highly efficient. A rapid optimization regarding catalyst loading and temperature showed that the best conditions required $0.11 \mathrm{~mol} \%$ of II in acetonitrile at $50{ }^{\circ} \mathrm{C}$ (Figure 6). Interestingly, under these conditions, maximum TON of 385 could be obtained in $6 \mathrm{~h}$. The inset B of Figure 7 shows a saturation profile for the initial rate of phenol production vs. catalyst concentration. This behavior is typical of an enzyme-like mechanism involving a rapid binding of the substrate.

The oxidation of cyclohexane, which is especially attractive and challenging, was studied in more detail and followed by the GC. Moreover, cyclohexane gives a minimum number of oxidation products which are easily identified by the GC method. As demonstrated previously 
in other oxidations [19,59-68], if the direct injection of a reaction sample into the chromatograph gave comparable amounts of cyclohexanol and cyclohexanone, the reduction of the sample with $\mathrm{PPh}_{3}$ (or certain sulfides) prior to GC analysis led to the noticeable predominance of the alcohol in many cases (Figure 8). The comparison of the results obtained before and after the reduction clearly indicated that cyclohexyl hydroperoxide was formed as the main primary product. The oxidation by the $\mathrm{II} / \mathrm{H}_{2} \mathrm{O}_{2} / \mathrm{CF}_{3} \mathrm{COOH}$ system was very efficient because it gave alkane oxidation products in a high GC yield of $48 \%(\mathrm{TON}=440)$ after $3 \mathrm{~h}$ at $20^{\circ} \mathrm{C}$.

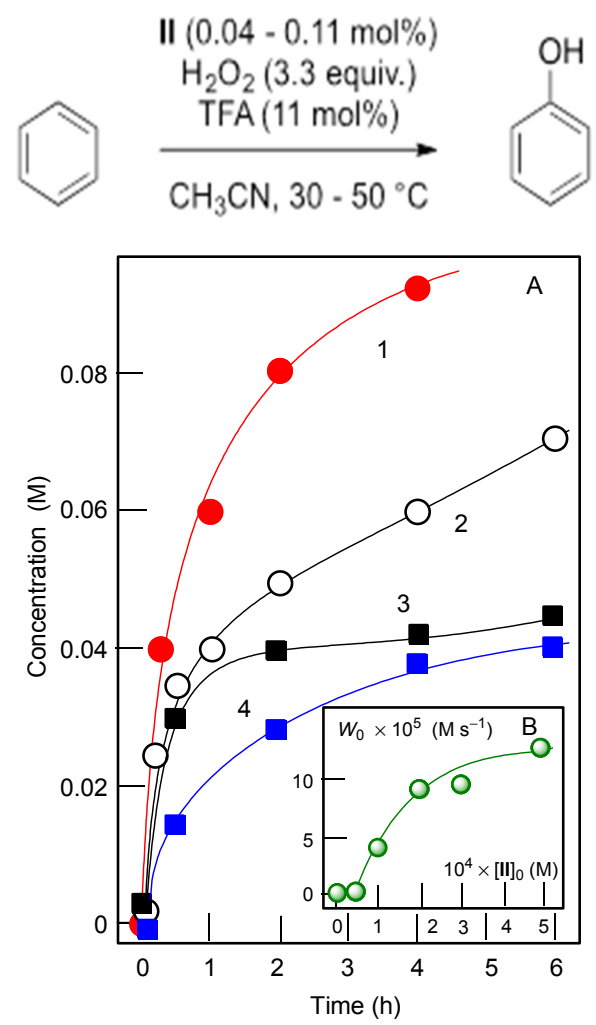

Figure 6. (Graph A) Accumulation of phenol with time. Benzene ( $0.46 \mathrm{M}), \mathrm{H}_{2} \mathrm{O}_{2}(50 \%$, aqueous, $1.5 \mathrm{M})$, catalyst II (5 $\times 10^{-4} \mathrm{M}$ for curve $1 ; 2 \times 10^{-4} \mathrm{M}$ for curves 2,3 and 4$), \mathrm{CF}_{3} \mathrm{COOH}(0.05 \mathrm{M})$ in $\mathrm{CH}_{3} \mathrm{CN}$ (total volume of the reaction solution was $5 \mathrm{~mL}$ ); temperature was $30^{\circ} \mathrm{C}$ (curves 3 and 4 ) or $50{ }^{\circ} \mathrm{C}$ (curves 1 and 2); (Graph B) Dependence of initial phenol accumulation rate $W_{0}$ on initial concentration of catalyst $[\mathrm{II}]_{0}$.

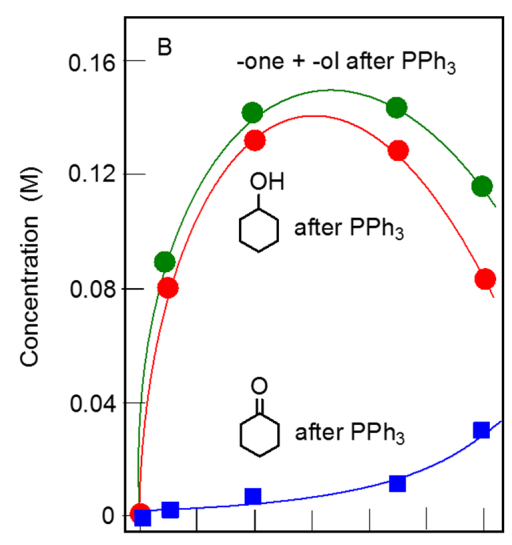

Figure 7. Cont. 


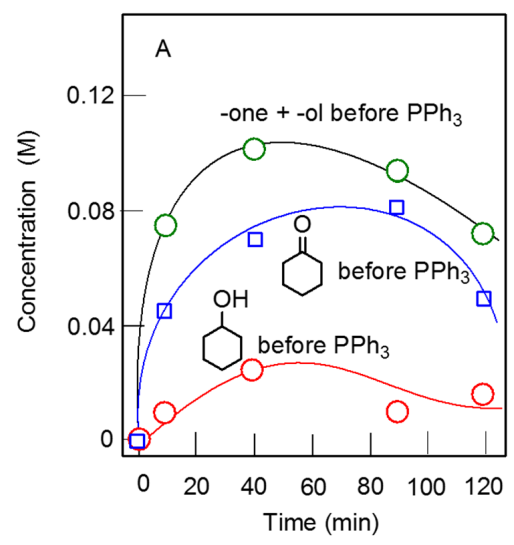

Figure 7. Accumulation of cyclohexanol and cyclohexanone with time. Cyclohexane $(0.46 \mathrm{M}), \mathrm{H}_{2} \mathrm{O}_{2}$ $(50 \%$, aqueous, $1.5 \mathrm{M})$, catalyst II $\left(5 \times 10^{-4} \mathrm{M}\right), \mathrm{CF}_{3} \mathrm{COOH}(0.05 \mathrm{M}), \mathrm{CH}_{3} \mathrm{CN}$ (total volume of the reaction solution was $5 \mathrm{~mL}$ ), $40{ }^{\circ} \mathrm{C}$. Concentrations measured by the GC method before (Graph A) and after (Graph B) reduction of the samples with $\mathrm{PPh}_{3}$ are shown (for this method, see References [19,59-68]).
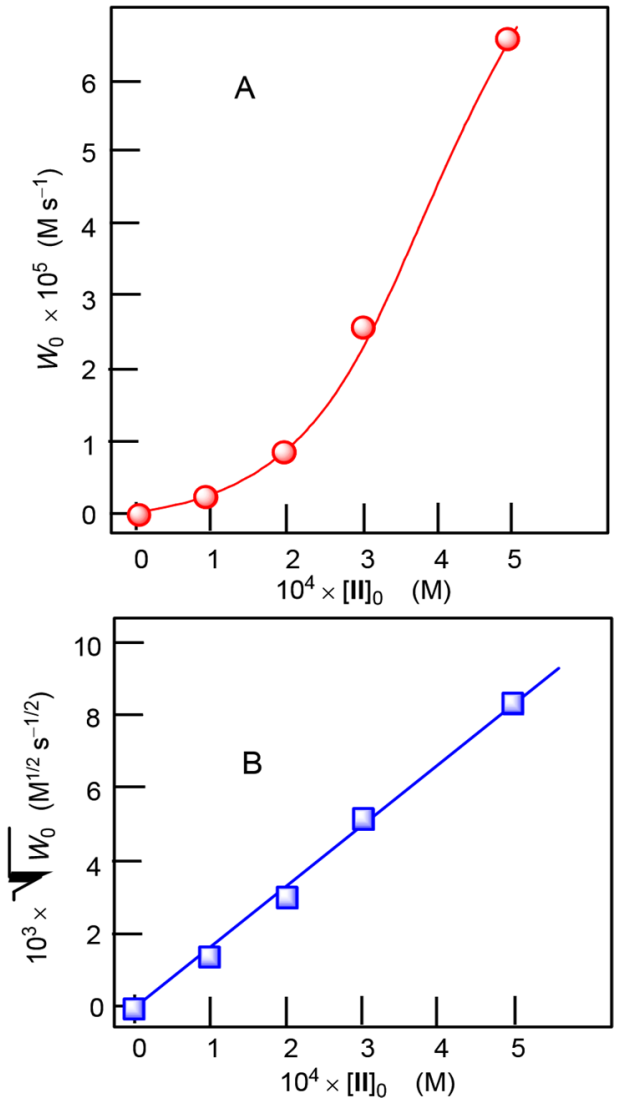

Figure 8. Dependence of the initial rate of formation cyclohexane oxidation products (the sum cyclohexanol + cyclohexanone) $W_{0}$ on initial concentration of catalyst II in the oxidation of cyclohexane $(0.46 \mathrm{M})$ with hydrogen peroxide $(50 \%$ aqueous, $1.5 \mathrm{M})$, catalyzed by compound II in the presence of $\mathrm{CF}_{3} \mathrm{COOH}(0.05 \mathrm{M})$ in $\mathrm{MeCN}$ at $40{ }^{\circ} \mathrm{C}$ (Graph A). Graph B: this dependence in coordinates " $W_{0}{ }^{1 / 2}$ vs. initial concentration of catalyst II". Concentrations of cyclohexanone and cyclohexanol were determined by the GC method after reduction of the aliquots with solid $\mathrm{PPh}_{3}$. 
The mode of dependence of the initial cyclohexane oxidation rate $W_{0}$ on concentration of catalyst II (Figure 9, Graph A) in the oxidation with hydrogen peroxide indicates that the rate of dependency is second order with respect to the initial concentration of II. Indeed, the proportional dependence of parameter $W_{0} \frac{1}{2}$ on $[\mathrm{II}]_{0}$ is presented by the straight line (Figure 9, Graph B). On the one hand, it is not probable that the quadratic dependence of $W_{0}$ on $[\mathrm{III}]_{0}$ is due to the dimerization of starting complexes containing six iron ions. It is important to note that dependence of $W_{0}$ on $[\mathbf{I I}]_{0}$ for the oxygenation of benzene to phenol (see Figure 7, Graph B) is also a quadratic one.

The role of added TFA in oxidations of alkanes and alcohols apparently was to split some bonds in the precatalyst cage, resulting in the formation of coordinatively unsaturated species active in $\mathrm{H}_{2} \mathrm{O}_{2}$ decomposition. In order to get additional insight into the mechanism of the alkane oxidation with the system under consideration, we carried out two experiments with cyclohexane. In the first experiment, we studied absorption spectra in the UV-visible region $\left(30 \times 10^{3}-13 \times 10^{3} \mathrm{~cm}^{-1}\right)$ under conditions that were similar to conditions of the kinetic oxidation experiments. Figure 10, Graph A demonstrates the absorption of complex II (in $\mathrm{CH}_{3} \mathrm{CN}$; [II $]=2.7 \times 10^{-4} \mathrm{M}$; curve 1). This absorption grows significantly when $\mathrm{CF}_{3} \mathrm{COOH}$ is added to the solution ([TFA] $=0.05 \mathrm{M}$, curve 2). If $\mathrm{H}_{2} \mathrm{O}_{2}$ (total concentration $1.3 \mathrm{M}$, containing $\left[\mathrm{H}_{2} \mathrm{O}\right]=2.4 \mathrm{M}$ ) is added to this acidified solution, the absorption decreases (curve 3). Addition of cyclohexane $(0.46 \mathrm{M})$ remains virtually the same spectrum (curve 4). Figure 10, Graph B corresponds to the spectrum obtained for higher concentration of initial complex II $\left(5.3 \times 10^{-4} \mathrm{M}\right.$, curve 1). In the presence of TFA $(0.05 \mathrm{M})$, the absorption is stronger (curve 2). Addition of water $\left(\left[\mathrm{H}_{2} \mathrm{O}\right]_{\text {added }}=4.9 \mathrm{M}\right)$ shifts curve 2 to the field of lower wavelength (curve 3$)$. Thus, obtained data indicate that addition of an acid strongly affects the absorption of the starting complex which can be due to certain changes of its structure, particularly the monomerization of initial hexameric complexes. The effect of the addition of $\mathrm{H}_{2} \mathrm{O}_{2}$ is similar to the influence of the additive of $\mathrm{H}_{2} \mathrm{O}$ (compare Figure 9, Graph A, curve 3, and Figure 9, Graph B, curve 3). It may be concluded that the changes in the presence of $\mathrm{H}_{2} \mathrm{O}_{2}$ are mainly due to the water which is introduced into the reaction solution simultaneously with hydrogen peroxide (50\% aqueous). As expected, addition of cyclohexane does not affect the catalyst (compare curves 3 and 4 in Figure 9, Graph A). Absorption of the catalyst is not practically changed in the course of the oxidation reaction; at least, in the first 90 min (compare curves 1 and 2 in Figure 9, Graph C). A small difference can be detected only after 180 min when $\mathrm{H}_{2} \mathrm{O}_{2}$ is practically deceased (see below, Figure 10).

We carried out the second experiment in order to determine stability and activity of the complex II during the course of cyclohexane oxidation. At the moment corresponding to the maximum concentration of formed oxygenates, when the oxidant concentration is low (denoted by an arrow in Figure 10), an additional portion of hydrogen peroxide was added. We see that the oxidation of cyclohexane restarts with the rate equal to the rate noticed in the beginning of the reaction. It can be concluded that, in accordance with the kinetic scheme given above, the dimeric iron complexes generated in the system from monomers take part in the catalytic decomposition of hydrogen peroxide.

Finally, it is necessary to note that complex II containing siloxane ligands is a much more efficient catalyst in the cyclohexane oxidation, in comparison with simple iron salts. Thus, if the GC yield of $48 \%(\mathrm{TON}=440)$ was attained after $3 \mathrm{~h}$ at $20^{\circ} \mathrm{C}$ in the II-catalyzed reaction, the oxygenate GC yield in the presence of $\mathrm{Fe}\left(\mathrm{NO}_{3}\right)_{3}$ under the same conditions was not higher than $1 \%-3 \%$. Complex II catalyzes the oxidation of normal heptane and methylcyclohexane (Figures S1 and S2). 

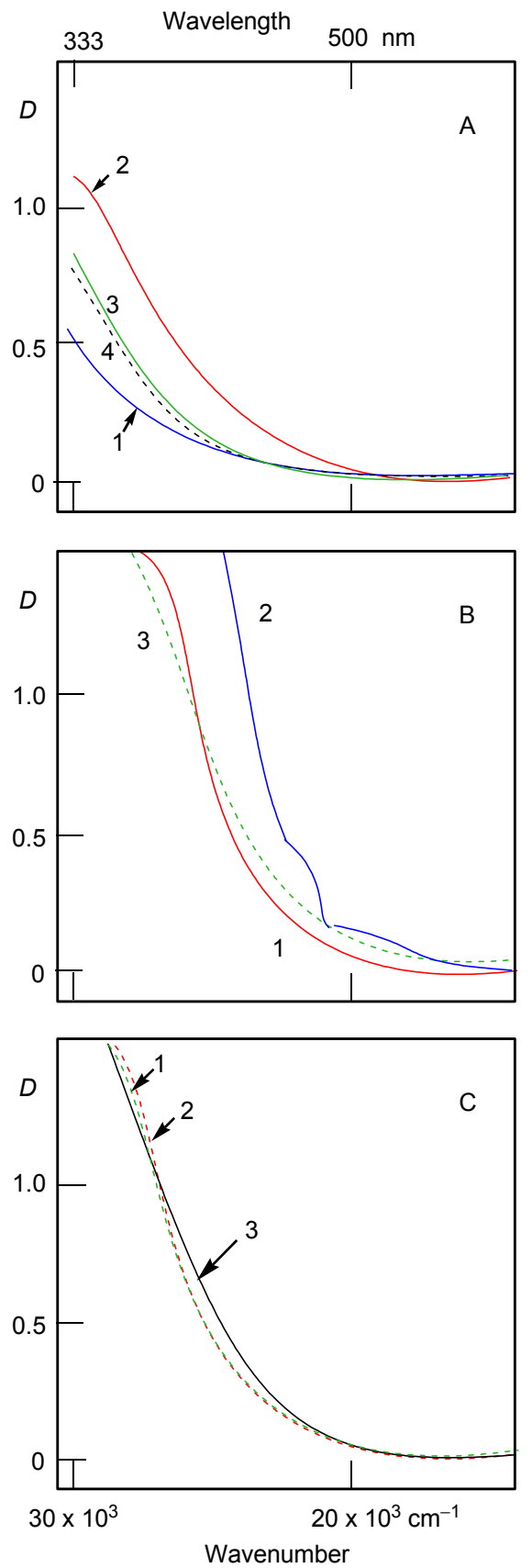

Figure 9. Electronic spectra of the pre-catalyst II solution in acetonitrile at $25{ }^{\circ} \mathrm{C}$ in the presence of various additives. (Graph A) Curve 1: a solution of II $\left(2.7 \times 10^{-4} \mathrm{M}\right), \mathrm{H}_{2} \mathrm{O}_{2}$, and cyclohexane in $\mathrm{MeCN}(2.5 \mathrm{~mL}$ ). Curve 2: the same solution after addition of TFA in MeCN (concentration of TFA $0.05 \mathrm{M})$. Curve 3: water $\left(\left[\mathrm{H}_{2} \mathrm{O}\right]_{\text {added }}=4.9 \mathrm{M}\right)$ was added to the solution corresponding to curve 2 . Curve 4: cyclohexane $(0.46 \mathrm{M})$ was added to the solution corresponding to curve 3; (Graph B) Curve 1: a solution of II $\left(5.3 \times 10^{-4} \mathrm{M}\right)$ in MeCN $(2.5 \mathrm{~mL})$. Curve 2: the same solution after addition of TFA in $\mathrm{MeCN}$ (concentration in the final solution was $0.05 \mathrm{M}$ ). Curve 3: hydrogen peroxide ( $50 \%$ aqueous, $1.3 \mathrm{M}$ containing $\left[\mathrm{H}_{2} \mathrm{O}\right]=2.4 \mathrm{M}$ ) was added to the solution corresponding to curve 2; (Graph $\mathrm{C}$ ) Curve 1: a solution of II $\left(4.7 \times 10^{-4} \mathrm{M}\right), \mathrm{H}_{2} \mathrm{O}_{2}$ and cyclohexane under conditions depicted by Figure 10, (Graph A) curve 4 in $\mathrm{MeCN}$ at the moment 5 min after preparation. Curve 2: The same solution after 90 (curve 2) and $180 \mathrm{~min}$ (curve 3) of incubation under conditions of cyclohexane oxidation experiments. 


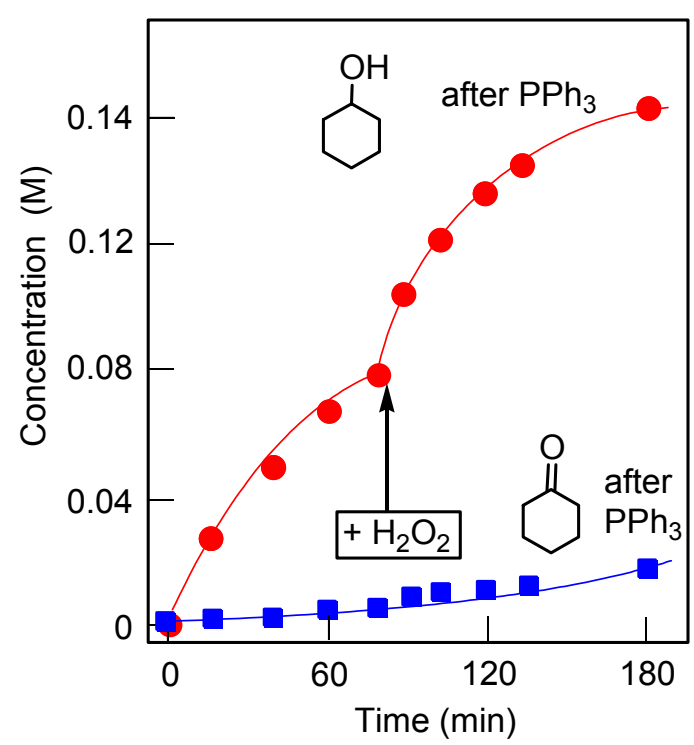

Figure 10. Accumulation of cyclohexanol and cyclohexanone with time. Conditions: Cyclohexane $(0.46 \mathrm{M}), \mathrm{H}_{2} \mathrm{O}_{2}(50 \%$, aqueous, $1.5 \mathrm{M})$, catalyst II $\left(2.5 \times 10^{-4} \mathrm{M}\right), \mathrm{CF}_{3} \mathrm{COOH}(0.05 \mathrm{M}), \mathrm{CH}_{3} \mathrm{CN}$ (total volume of the reaction solution was $5 \mathrm{~mL}$ ), $40{ }^{\circ} \mathrm{C}$. At the moment denoted by an arrow, an additional portion of hydrogen peroxide (the same amount as in the beginning of the reaction) was added. Concentrations were measured after reduction of the samples with $\mathrm{PPh}_{3}$.

\section{Materials and Methods}

Starting compound $\mathrm{PhSi}(\mathrm{OEt})_{3}$ and all solvents were purchased from Sigma Aldrich and were used as received. IR spectra were recorded on FTIR Shimadzu IR Prestige-21. IR spectrum in Nujol for solids and liquid solution in thin film were obtained using $\mathrm{KBr}$ discs.

\subsection{Synthesis of Compound $\mathbf{I}$}

Compound $\mathrm{PhSi}(\mathrm{OEt})_{3}(2 \mathrm{~g}, 8.32 \mathrm{mmol})$ and sodium hydroxide $(0.333 \mathrm{~g}, 8.32 \mathrm{mmol})$ were dissolved in $45 \mathrm{~mL}$ of $\mathrm{MeOH}$. After complete dissolution of sodium hydroxide, the mixture was heated at reflux for $2.5 \mathrm{~h}$, and then iron(III) chloride $(0.338 \mathrm{~g}, 2.08 \mathrm{mmol})$ in $60 \mathrm{~mL}$ of acetonitrile was added. The resulting brick-colored solution was additionally heated at reflux for $1 \mathrm{~h}$ and then cooled down to room temperature. Formation of a crystalline product with single crystals, useful for X-ray diffraction analysis (see below), was observed in solution after approximately three weeks. After ceasing of the crystal fraction growth, the solution was decanted and the solid fraction was dried in a vacuum without heating. Product I ( $0.22 \mathrm{~g} ; 16 \%$ yield) was obtained.

Elemental analysis calcd. $\left[\left(\mathrm{PhSiO}_{1.5}\right)_{20}\left(\mathrm{FeO}_{1.5}\right)_{6}\left(\mathrm{NaO}_{0.5}\right)_{7}\right]: \mathrm{Fe}, 10.22 ; \mathrm{Na}, 4.91 ; \mathrm{Si}, 17.13$. Found: $\mathrm{Fe}$, $10.19 ; \mathrm{Na}, 4.82 ; \mathrm{Si}, 17.04$.

\subsection{Synthesis of Compound II}

Compound $\mathrm{PhSi}(\mathrm{OEt})_{3}(4 \mathrm{~g}, 16.64 \mathrm{mmol})$ and sodium hydroxide $(0.96 \mathrm{~g}, 24 \mathrm{mmol})$ were dissolved in $30 \mathrm{~mL}$ of $\mathrm{MeOH}$. After complete dissolution of sodium hydroxide, the mixture was heated at reflux for $2.5 \mathrm{~h}$, and then iron(III) chloride $(0.90 \mathrm{~g}, 5.55 \mathrm{mmol})$ in $100 \mathrm{~mL}$ of acetonitrile was added. The resulting brick-colored solution was heated at reflux for $2 \mathrm{~h}$, then cooled down and filtered. Formation of a crystalline brick-colored product was observed in approximately two weeks. Several single crystals were used for X-ray diffraction analysis (see details below). After ceasing of the crystal fraction growth, the solution was decanted and the solid fraction was dried in a vacuum without heating. Product II $(0.73 \mathrm{~g}, 26 \%$ yield $)$ was obtained. 
Elemental analysis calcd. [( $\left.\left.\mathrm{PhSiO}_{2}\right)_{18} \mathrm{Fe}_{6} \mathrm{Na}_{6}(\mathrm{O})_{3}\right]: \mathrm{Fe}, 11.20 ; \mathrm{Na}, 4.61 ; \mathrm{Si}, 16.91$. Found: $\mathrm{Fe}, 10.81 ; \mathrm{Na}$, $4.41 ; \mathrm{Si}, 16.63$.

\subsection{X-ray Studies}

The X-ray diffraction intensities of single crystals of compound I were measured at the Kurchatov Centre for Synchrotron radiation, while the dataset for II was collected with Bruker APEX DUO diffractometer. The structures were solved by direct method and refined in anisotropic approximation. Hydrogen atoms were calculated from a geometrical point of view, and were then refined with restraints applied for their displacement parameters and $\mathrm{C}-\mathrm{H}(\mathrm{O}-\mathrm{H})$ bond length. The crystal data for compounds I and II are summarized in Table 2 (see also the ESI).

Crystallographic data for I and II were submitted to CSD (CCDC 1481141 and CCDC 1481142) and can be obtained free of charge using web request from http://www.ccdc.cam.ac.uk/request.

Table 2. Results of X-ray experiments for complexes I and II.

\begin{tabular}{|c|c|c|}
\hline Compound & I & II \\
\hline Brutto formula & $\mathrm{C}_{133 \cdot 50} \mathrm{H}_{128 \cdot 25} \mathrm{Fe}_{6} \mathrm{~N}_{5 \cdot 75} \mathrm{Na}_{7} \mathrm{O}_{46} \mathrm{Si}_{20}$ & $\mathrm{C}_{125} \mathrm{H}_{117.96} \mathrm{Fe}_{6} \mathrm{~N}_{8.5} \mathrm{Na}_{6} \mathrm{O}_{44.36} \mathrm{Si}_{18}$ \\
\hline Formula weight & 3606.99 & 3427.79 \\
\hline Wavelength, $\AA$ & 0.96600 & 1.5418 \\
\hline$T, \mathrm{~K}$ & 100 & 120 \\
\hline Space group & $\mathrm{P} 2_{1} / \mathrm{n}$ & Pn \\
\hline$Z^{-1}$ & 4 & 2 \\
\hline$a, \AA$ & $27.130(5)$ & $17.7227(10)$ \\
\hline$b, \AA$ & $18.150(4)$ & $15.9140(9)$ \\
\hline$c, \AA$ & $32.830(7)$ & 28.4984(17) \\
\hline$\beta,^{\circ}$ & $91.75(3)$ & $100.136(3)$ \\
\hline$V, \AA^{3}$ & $16158(6)$ & $7912.2(8)$ \\
\hline$\rho_{\text {calc }}, \mathrm{g} \cdot \mathrm{cm}^{-3}$ & 1.483 & 1.439 \\
\hline$\mu, \mathrm{cm}^{-1}$ & 17.86 & 64.35 \\
\hline$F(000)$ & 7402 & 3513 \\
\hline $2 \theta_{\max }^{\circ}$ & 70.84 & 135.72 \\
\hline Reflections collected & 234,993 & 20,450 \\
\hline Independent reflections & 22,897 & 20,450 \\
\hline Independent reflections with $I>2 \sigma(\mathbf{I})$ & 18,123 & 17,065 \\
\hline Parameters & 1681 & 1825 \\
\hline$R_{1}[\mathbf{I}>2 \sigma(\mathbf{I})]$ & 0.1274 & 0.0925 \\
\hline $\mathrm{w} R_{2}$ (all reflections) & 0.2763 & 0.2347 \\
\hline GOF & 1.065 & 0.973 \\
\hline Residual electron density, e. $\AA^{3}\left(\rho_{\min } / \rho_{\max }\right)$ & $1.72 /-1.10$ & $2.08 /-1.15$ \\
\hline
\end{tabular}

The main difficulty in the refinement of compounds I and II was to reveal the exact chemical composition of these structures. At first sight, positive and negative charges in these structures are imbalanced. This could be due to localization of counterions and hydrogen atoms attached to oxygen or nitrogen atoms due to disorder. In the case of $\mathbf{I}$, we decided to treat the water molecule coordinated to $\mathrm{Na}$ as an oxonium cation $\mathrm{H}_{3} \mathrm{O}^{+}$.

\subsection{Oxidation of Alcohols and Hydrocarbons with Peroxides}

The reactions of alcohols and hydrocarbons were usually carried out in air in thermostated Pyrex cylindrical vessels with vigorous stirring, using $\mathrm{MeCN}$ as solvent. Typically, catalyst II and the co-catalyst (acid) were introduced into the reaction mixture in the form of stock solutions in acetonitrile. The substrate (alcohol or hydrocarbon) was then added and the reaction started when hydrogen peroxide or TBHP was introduced in one portion. (CAUTION: The combination of air or molecular oxygen and $\mathrm{H}_{2} \mathrm{O}_{2}$ with organic compounds at elevated temperatures may be explosive). The reactions with benzene and 1-phenyethanol were analyzed by ${ }^{1} \mathrm{H}$ NMR method (solutions in acetone- $d_{6}$; "Bruker AMX-400" instrument, $400 \mathrm{MHz}$ ). For the determination of concentrations of phenol and quinone, 
signals in the aromatic region were integrated using added 1,4-dinitrobenzene as a standard. Areas of methyl group signals were measured to quantify oxygenates formed in oxidations of 1-phenylethnaol. In order to determine concentrations of all cyclohexane oxidation products, the samples of reaction solutions after addition of nitromethane as a standard compound were in some cases analyzed twice (before and after their treatment with $\mathrm{PPh}_{3}$ ) by GC (LKhM-80-6 instrument, columns $2 \mathrm{~m}$ with 5\% Carbowax 1500 on $0.25-0.315$ mm Inerton AW-HMDS; carrier gas, argon) to measure concentrations of cyclohexanol and cyclohexanone. This method (an excess of solid triphenylphosphine was added to the samples 10-15 min before the GC analysis) was proposed by one of us earlier [19,59-68]. Attribution of peaks was made by comparison with chromatograms of authentic samples. Blank experiments with cyclohexane showed that, in the absence of catalyst II, no products were formed.

\subsection{Selectivity in the Alkane Oxidations}

In order to get an insight into the nature of oxidizing species, we measured the selectivity parameters in oxidations of certain linear, branched, and cyclic saturated hydrocarbons with $\mathrm{H}_{2} \mathrm{O}_{2}$. The regioselectivity parameter [relative normalized reactivities of $\mathrm{H}$ atoms at carbon atoms $\mathrm{C}(1)$, $\mathrm{C}(2), \mathrm{C}(3)$, and $\mathrm{C}(4)$ of $n$-octane chain] determined for the oxidation of $n$-octane is relatively low, i.e., $C(1): C(2): C(3): C(4)=1.0: 6.7: 6.6: 6.1$. It can be seen that hydrogen atoms in position 4 posess lower activity, aparently due to some sterical hindrance $[50,57,60]$. The bond-selectivity parameter $\left(1^{\circ}: 2^{\circ}: 3^{\circ}\right.$; the relative normalized reactivities of hydrogen atoms at the primary, secondary, and tertiary carbons) in the oxidation of methylcyclohexane (1.0:6.7:17.5) is close to the corresponding values found for the systems oxidizing alkanes with hydroxyl radicals (see, for example, References [69-75]). The oxidation of cis-1,2-dimethylcyclohexane proceeds non-stereoselectively, because the trans/cis ratio [the ratio of isomers of tert-alcohols with mutual trans- and cis-orientation of two methyl groups] of isomeric alcohols (after reduction with $\mathrm{PPh}_{3}$ ) was 0.8 . The oxygenation of methylcyclohexane (MCH) with $\mathrm{H}_{2} \mathrm{O}_{2}$ proceeds mainly at the tertiary carbon atom with formation of 1-methylcyclohexanol after reduction with $\mathrm{PPh}_{3}$ (product P5; see Supplementary Materials Figures S1 and S2). The GC profile of the products obtained in the II-catalyzed oxidation is very similar to the profiles reported previously for some other systems which oxidize with the participation of hydroxyl radicals (see Figure S2). All these data testify that an oxidizing species generated by the system exhibits a low selectivity typical for hydroxyl radicals.

\subsection{General Procedure for Catalytic Amide Formation}

In a sealed tube were added successively amine hydrochloride $(0.5 \mathrm{mmol}), \mathrm{CaCO}_{3}(25.0 \mathrm{mg}$, $0.25 \mathrm{mmol}), \mathrm{CH}_{3} \mathrm{CN}(1 \mathrm{~mL}), \mathrm{II}$ (50 $\mu \mathrm{L}$ of a solution of $2.8 \mathrm{mg}$ of II in $1 \mathrm{~mL}$ of $\mathrm{CH}_{3} \mathrm{CN}$ ), benzylic alcohol $(104 \mu \mathrm{L}, 1.0 \mathrm{mmol})$, and TBHP $\left(70 \%\right.$ in $\left.\mathrm{H}_{2} \mathrm{O}, 140 \mu \mathrm{L}, 1.0 \mathrm{mmol}\right)$. The mixture was stirred at $80^{\circ} \mathrm{C}$ for $2 \mathrm{~h}$, and TBHP $\left(70 \%\right.$ in $\left.\mathrm{H}_{2} \mathrm{O}, 140 \mu \mathrm{L}, 1.0 \mathrm{mmol}\right)$ was again added to the mixture. After $16 \mathrm{~h}$ at $80^{\circ} \mathrm{C}$, the mixture was cooled to room temperature, and $1 \mathrm{~N} \mathrm{HCl}$ and $\mathrm{AcOEt}$ were added. The mixture was extracted twice with $\mathrm{AcOEt}$, and the combined organic phase was washed with a saturated solution of $\mathrm{NaHCO}_{3}$, brine, and concentrated under reduced pressure. To remove the excess of benzylic alcohol, $80 \mathrm{~mL}$ of $\mathrm{H}_{2} \mathrm{O}$ was added and evaporated under reduced pressure. Crude product was then purified using silica gel chromatography using gradients of cyclohexane/AcOEt to yield the pure compounds. The spectra of prepared amides are presented in the supplementary file ESI.

\section{Conclusions}

Two heterometallic $\left(\mathrm{Fe}_{6} \mathrm{Na}_{7}\right)$ silsesquioxanes- $\left\{\left[\mathrm{Ph}_{5} \mathrm{Si}_{5} \mathrm{O}_{10}\right]_{2}\left[\mathrm{Ph}_{10} \mathrm{Si}_{10} \mathrm{O}_{21}\right] \mathrm{Fe}_{6}\left(\mathrm{O}^{2-}\right)_{2} \mathrm{Na}_{7}\left(\mathrm{H}_{3} \mathrm{O}^{+}\right)\right.$ $\left.(\mathrm{MeOH})_{2}(\mathrm{MeCN})_{4.5}\right\} .1 .25(\mathrm{MeCN}), \mathbf{I}$, and $\left[\mathrm{Ph}_{5} \mathrm{Si}_{5} \mathrm{O}_{10}\right]_{2}\left[\mathrm{Ph}_{4} \mathrm{Si}_{4} \mathrm{O}_{8}\right]_{2} \mathrm{Fe}_{6} \mathrm{Na}_{6}\left(\mathrm{O}^{2-}\right)_{3}(\mathrm{MeCN})_{8.5}\left(\mathrm{H}_{2} \mathrm{O}\right)_{8.44}$, II-were prepared using acetonitrile as a key reaction media. $\mathrm{X}$-ray studies established the presence of Fe-O-Fe units in the composition of both products, which could be explained by additional rearrangement of metallasilsesquioxane skeletons before crystallization. A scheme of rearrangement is proposed. Compound II was found to be a highly active precatalyst in the oxidative amidation of 
alcohols and amines. Amides could be isolated with TON/TOF values up to $1540 / 86 \mathrm{~h}^{-1}$. Experiments on the oxidation of alcohols, benzene, and cyclohexane with the $\mathrm{II} / \mathrm{H}_{2} \mathrm{O}_{2} / \mathrm{CF}_{3} \mathrm{COOH}$ system were also very efficient. Importantly, this oxidative system was revealed to be particularly efficient for the oxidation of cyclohexane, yielding oxygenate derivatives in yield $48 \%$ and TON up to 440 . Thus, this oxidation system is superior one because its activity much higher than the efficiency of oxidation catalyzed, for example, by nonanuclear $\mathrm{Cu}(\mathrm{II})$-silsesquioxane, $\left[\left(\mathrm{MeSiO}_{1.5}\right)_{18}(\mathrm{CuO})_{9}\right]$, reported by us very recently (total yield was $20 \%$, TON 184) [76].

Supplementary Materials: The following are available online at www.mdpi.com/2073-4344/7/4/101/s1, X-ray Studies; Figure S1: Isomeric products formed in the methylcyclohexane oxidation; Figure S2: A chromatogram of products obtained in oxidations of methylcyclohexane by the " $\mathrm{H}_{2} \mathrm{O}_{2}$-II-CF3COOH" system; Kinetic analysis of cyclohexane oxidation; Description of amides; References for the ESI.

Acknowledgments: This work was partially financially supported by the Ministry of Education and Science of the Russian Federation (the Agreement number 02.a03.21.0008), the RFBR (projects 16-29-05180 and 16-03-00254), RFBR-CNRS (project 16-53-150008), the French Embassy in Moscow, the Balard Foundation, and Université de Montpellier.

Author Contributions: A.N.B., F.L. and G.B.S. conceived and designed the experiments; A.I.Y., P.V.D., A.A.K., V.N.K., M.A.E., X.B., B.V. and L.S.S. performed the experiments; A.N.B., F.L., Y.N.K., E.S.S., A.A.K., V.N.K. and G.B.S. analyzed the data; E.S.S. and J.M. contributed reagents/materials/analysis tools; A.N.B., M.M.L., F.L. and G.B.S. wrote the paper.

Conflicts of Interest: The authors declare no conflict of interest.

\section{Abbreviations}

TON

TBHP

GC

TFA turnover number

tert-butylhydroperoxide

gas liquid chromatography

trifluoroacetic acid

\section{References}

1. Larsen, F.K.; McInnes, E.J.L.; Mkami, H.E.; Overgaard, J.; Piligkos, S.; Rajaraman, G.; Rentschler, E.; Smith, A.A.; Smith, G.M.; Boote, V.; et al. Synthesis and Characterization of Heterometallic $\{\mathrm{Cr} 7 \mathrm{M}\}$ Wheels. Angew. Chem. Int. Ed. 2003, 42, 101-105. [CrossRef]

2. Saalfrank, R.W.; Prakash, R.; Maid, H.; Hampel, F.; Heinemann, F.W.; Trautwein, A.X.; Bçttger, L.H. Synthesis and Characterization of Metal-Centered, Six-Membered, Mixed-Valent, Heterometallic Wheels of Iron, Manganese, and Indium. Chem. Eur. J. 2006, 12, 2428-2433. [CrossRef] [PubMed]

3. Moushi, E.E.; Lampropoulos, C.; Wernsdorfer, W.; Nastopoulos, V.; Christou, G.; Tasiopoulos, A.J. A Large [ $\mathrm{Mn}_{10} \mathrm{Na}_{4}$ Loop of Four Linked Mn10 Loops. Inorg. Chem. 2007, 46, 3795-3797. [CrossRef] [PubMed]

4. Milway, V.A.; Tuna, F.; Farrell, A.R.; Sharp, L.E.; Parsons, S.; Murrie, M. Directed Synthesis of $\left\{\mathrm{Mn}_{18} \mathrm{Cu}_{6}\right\}$ Heterometallic Complexes. Angew. Chem. Int. Ed. 2013, 52, 1949-1952. [CrossRef] [PubMed]

5. Ojea, M.J.H.; Wilson, C.; Coles, S.J.; Tunac, F.; Murrie, M. Directed synthesis of $\left\{\mathrm{Cu}^{\mathrm{II}_{2}} \mathrm{Zn}^{\mathrm{II}}{ }_{2}\right\}$ and $\left\{\mathrm{Cu}_{8}{ }_{8} \mathrm{Zn}_{8}{ }_{8}{ }_{8}\right\}$ heterometallic complexes. Dalton Trans. 2015, 44, 19275-19281. [CrossRef] [PubMed]

6. Singh, S.; Roesky, H.W. Robust and efficient molecular catalysts with a $\mathrm{M}-\mathrm{O}-\mathrm{M}^{\prime}$ framework. Dalton Trans. 2007, 1360-1370. [CrossRef] [PubMed]

7. Mata, J.A.; Hahn, F.E.; Peris, E. Heterometallic complexes, tandem catalysis and catalytic cooperativity. Chem. Sci. 2014, 5, 1723-1732. [CrossRef]

8. Buchwalter, P.; Rosé, J.; Braunstein, P. Multimetallic Catalysis Based on Heterometallic Complexes and Clusters. Chem. Rev. 2015, 115, 28-126. [CrossRef] [PubMed]

9. Piquer, L.R.; Sañudo, E.C. Heterometallic 3d-4f single-molecule magnets. Dalton Trans. 2015, 44, 8771-8780. [CrossRef] [PubMed]

10. Roques, N.; Mugnaini, V.; Veciana, J. Magnetic and porous molecule-based materials. Top. Curr. Chem. 2010, 293, 207-258. [PubMed] 
11. Costantino, F.; Ienco, A.; Taddei, M. Hybrid multifunctional materials based on phosphonates, phosphinates and auxiliary ligands. In Tailored Organic-Inorganic Materials; Brunet, E., Colón, J.L., Clearfield, A., Eds.; John Wiley \& Sons, Inc.: Hoboken, NJ, USA, 2015.

12. Pardo, E.; Ruiz-Garcia, R.; Cano, J.; Ottenwaelder, X.; Lescouezec, R.; Journaux, Y.; Lloret, F.; Julve, M. Ligand design for multidimensional magnetic materials: A metallosupramolecular perspective. Dalton Trans. 2008, 2780-2805. [CrossRef] [PubMed]

13. Dul, M.-C.; Pardo, E.; Lescouëzec, R.; Journaux, Y.; Ferrando-Soriac, J.; Ruiz-García, R.; Cano, J.; Julve, M.; Lloret, F.; Cangussu, D.; et al. Supramolecular coordination chemistry of aromatic polyoxalamide ligands: A metallosupramolecular approach toward functional magnetic materials. Coord. Chem. Rev. 2010, 254, 2281-2296. [CrossRef]

14. Murugavel, R.; Voigt, A.; Walawalkar, M.G.; Roesky, H.W. Hetero- and Metallasiloxanes Derived from Silanediols, Disilanols, Silanetriols, and Trisilanols. Chem. Rev. 1996, 96, 2205-2236. [CrossRef] [PubMed]

15. Lorenz, V.; Fischer, A.; Gießmann, S.; Gilje, J.W.; Gun'ko, Y.; Jacob, K.; Edelmann, F.T. Disiloxanediolates and polyhedral metallasilsesquioxanes of the early transition metals and f-elements. Coord. Chem. Rev. 2000, 206-207, 321-368. [CrossRef]

16. Ward, A.J.; Masters, A.F.; Maschmeyer, T. Metallasilsesquioxanes: Molecular Analogues of Heterogeneous Catalysts. Adv. Silicon Sci. 2011, 3, 135-166.

17. Levitsky, M.M.; Bilyachenko, A.N. Modern Concepts and Methods in the Chemistry of Polyhedral Metallasiloxanes. Coord. Chem. Rev. 2016, 306, 235-269. [CrossRef]

18. Pinkert, D.; Limberg, C. Iron Silicates, Iron-Modulated Zeolite Catalysts, and Molecular Models Thereof. Chem. Eur. J. 2014, 20, 9166-9175. [CrossRef] [PubMed]

19. Shul'pin, G.B. New Trends in Oxidative Functionalization of Carbon-Hydrogen Bonds: A Review. Catalysts 2016, 6, 50. [CrossRef]

20. Levitsky, M.M.; Yalymov, A.I.; Kulakova, A.N.; Petrov, A.A.; Bilyachenko, A.N. Cage-like metallasilsesquioxanes in catalysis: A review. J. Mol. Catal. A Chem. 2017, 426, 297-304. [CrossRef]

21. Bilyachenko, A.N.; Yalymov, A.I.; Korlyukov, A.A.; Long, J.; Larionova, J.; Guari, Y.; Zubavichus, Y.V.; Trigub, A.L.; Shubina, E.S.; Eremenko, I.L.; et al. Heterometallic $\mathrm{Na}_{6} \mathrm{Co}_{3}$ Phenylsilsesquioxane Exhibiting Slow Dynamic Behavior in its Magnetization. Chem. Eur. J. 2015, 21, 18563-18565. [CrossRef] [PubMed]

22. Bilyachenko, A.N.; Yalymov, A.I.; Korlyukov, A.A.; Long, J.; Larionova, J.; Guari, Y.; Vologzhanina, A.V.; Eskova, M.A.; Shubina, E.S.; Levitsky, M.M. Unusual penta- and hexanuclear Ni(II)-based silsesquioxane polynuclear complexes. Dalton Trans. 2016, 45, 7320-7327. [CrossRef] [PubMed]

23. Bilyachenko, A.N.; Levitsky, M.M.; Yalymov, A.I.; Korlyukov, A.A.; Vologzhanina, A.V.; Kozlov, Y.N.; Shul'pina, L.S.; Nesterov, D.; Pombeiro, A.F.; Lamaty, F.; et al. Heterometallic (Fe6Na8) Cage-like Silsesquioxane: Synthesis, Structure, Spin Glass Behavior and High Catalytic Activity. RSC Adv. 2016, 6, 48165-48180. [CrossRef]

24. Bilyachenko, A.N.; Yalymov, A.I.; Levitsky, M.M.; Korlyukov, A.A.; Eskova, M.A.; Long, J.; Larionova, J.; Guari, Y.; Shul'pina, L.S.; Ikonnikov, N.S.; et al. First Cage-Like Pentanuclear Co(II)-Silsesquioxane. Dalton Trans. 2016, 45, 13663-13666. [CrossRef] [PubMed]

25. Roesky, H.W.; Anantharaman, G.; Chandrasekhar, V.; Jancik, V.; Singh, S. Control of Molecular Topology and Metal Nuclearity in Multimetallic Assemblies: Designer Metallosiloxanes Derived from Silanetriols. Chem. Eur. J. 2004, 10, 4106-4114. [CrossRef] [PubMed]

26. Lorenz, V.; Edelmann, F.T. Metallasilsesquioxanes. Adv. Organomet. Chem. 2005, 53, 101-153.

27. Jutzi, P.; Lindemann, H.M.; Nolte, J.-O.; Schneider, M. Synthesis, structure, and reactivity of novel oligomeric titanasiloxanes. In Silicon Chemistry: From the Atom to Extended Systems; Jutzi, P., Schubert, U., Eds.; Wiley: Hoboken, NJ, USA, 2007; pp. 372-382.

28. Edelmann, F.T. Metallasilsesquioxanes. Synthetic and structural studies. In Silicon Chemistry: From the Atom to Extended Systems; Jutzi, P., Schubert, U., Eds.; Wiley: Hoboken, NJ, USA, 2007; pp. 383-394.

29. Hirotsu, M.; Taruno, S.; Yoshimura, T.; Ueno, K.; Unno, M.; Matsumoto, H. Synthesis and Structures of the First Titanium(IV) Complexes with Cyclic Tetrasiloxide Ligands: Incomplete and Complete Cage Titanosiloxanes. Chem. Lett. 2005, 34, 1542-1543. [CrossRef]

30. Anderson, T.M.; Zhang, X.; Hardcastle, K.I.; Hill, C.L. Reactions of Trivacant Wells-Dawson Heteropolytungstates. Ionic Strength and Jahn-Teller Effects on Formation in Multi-Iron Complexes. Inorg. Chem. 2002, 41, 2477-2488. [CrossRef] [PubMed] 
31. Wang, J.; Zhao, J.-W.; Zhao, H.-Y.; Yang, B.-F.; He, H.; Yang, G.-Y. Syntheses, structures and properties of two multi-iron-samarium/multi-iron substituted germanotungstates. CrystEngComm 2014, 16, 252-259. [CrossRef]

32. Zhao, J.; Han, Q.; Shi, D.; Chen, L.; Ma, P.; Wang, J.; Niu, J. Synthesis, structure and magnetism of a S-shaped multi-iron substituted arsenotungstate containing a trivacant Keggin [B- $\left.\alpha-\mathrm{AsVW}_{9} \mathrm{O}_{34}\right]^{9-}$ and a hexavacant Keggin $\left[\alpha-\mathrm{AsVW}_{6} \mathrm{O}_{26}\right]^{11-}$ fragments. J. Solid State Chem. 2011, 184, 2756-2761. [CrossRef]

33. Caneschi, A.; Cornia, A.; Fabretti, A.C.; Gatteschi, D.; Malavasi, W. Polyiron(III)-Alkoxo Clusters: A Novel Trinuclear Complex and Its Relevance to the Extended Lattices of Iron Oxides and Hydroxide. Inorg. Chem. 1995, 34, 4660-4668. [CrossRef]

34. Li, B.; Zhao, J.-W.; Zheng, S.-T.; Yang, G.-Y. A banana-shaped iron(III)-substituted tungstogermanate containing two types of lacunary polyoxometalate units. Inorg. Chem. Comm. 2009, 12, 69-71. [CrossRef]

35. Levitsky, M.M. Metallasiloxanes and lithosphere. Russ. Chem. J. 2002, XLVI, 51-63.

36. Bilyachenko, A.N.; Zavin, B.G.; Shubina, E.S.; Filin, A.M.; Levitsky, M.M. Intermolecular rearrangement of cobalt phenylsiloxanes. Russ. Chem. Bull. 2004, 53, 1993-1995. [CrossRef]

37. Levitsky, M.M.; Zavin, B.G.; Bilyachenko, A.N. Chemistry of metallasiloxanes. Current trends and new concepts. Russ. Chem. Rev. 2007, 76, 847-866. [CrossRef]

38. Pietschnig, R.; Spirk, S. The chemistry of organo silanetriols. Coord. Chem. Rev. 2016, 323, 87-106. [CrossRef]

39. Čas, D.; Hurkes, N.; Spirk, S.; Belaj, F.; Bruhn, C.; Rechberger, G.N.; Pietschnig, R. Dimer formation upon deprotonation: Synthesis and structure of a m-terphenyl substituted (R,S)-dilithium disiloxanolate disilanol. Dalton Trans. 2015, 44, 12818-12823. [CrossRef] [PubMed]

40. Hurkes, N.; Bruhn, C.; Belaj, F.; Pietschnig, R. Silanetriols as Powerful Starting Materials for Selective Condensation to Bulky POSS Cages. Organometallics 2014, 33, 7299-7306. [CrossRef] [PubMed]

41. Yalymov, A.I.; Dronova, M.S.; Filippov, O.A.; Bilyachenko, A.N.; Levitsky, M.M. Quantum chemical study of the template synthesis of cage-like metallasiloxanes. Russ. Chem. Bull. 2014, 63, 821-825. [CrossRef]

42. Bilyachenko, A.N.; Dronova, M.S.; Yalymov, A.I.; Lamaty, F.; Bantreil, X.; Martinez, J.; Bizet, C.; Shul'pina, L.S.; Korlyukov, A.A.; Arkhipov, D.E.; et al. Cage-like Copper(II) Silsesquioxanes: Transmetalation Reactions and Structural, Quantum Chemical, and Catalytic Studies. Chem. Eur. J. 2015, 21, 8758-8770. [CrossRef] [PubMed]

43. Tan, G.; Yang, Y.; Chu, C.; Zhu, H.; Roesky, H.W. $\mathrm{Cu}_{24} \mathrm{O}_{24} \mathrm{Si}_{8} \mathrm{R}_{8}$ : Organic Soluble 56-Membered Copper(I) Siloxane Cage and Its Use in Homogeneous Catalysis. J. Am. Chem. Soc. 2010, 132, 12231-12233. [CrossRef] [PubMed]

44. Bantreil, X.; Kanfar, N.; Gehin, N.; Golliard, E.; Ohlmann, P.; Martinez, J.; Lamaty, F. Iron-catalyzed benzamide formation. Application to the synthesis of moclobemide. Tetrahedron 2014, 70, 5093-5099. [CrossRef]

45. Bantreil, X.; Navals, P.; Martinez, J.; Lamaty, F. Iron/Caffeine as a Catalytic System for Microwave-Promoted Benzamide Formation. Eur. J. Org. Chem. 2015, 417-422. [CrossRef]

46. De Araújo, M.L.; Mandelli, D.; Kozlov, Y.N.; Carvalho, W.A.; Shul'pin, G.B. Oxidation of hydroxyacetone (acetol) with hydrogen peroxide in acetonitrile solution catalyzed by iron(III) chloride. J. Mol. Catal. A Chem. 2016, 422, 103-114. [CrossRef]

47. Shilov, A.E.; Shul'pin, G.B. Activation of C-H Bonds by Metal Complexes. Chem. Rev. 1997, 97, $2879-2932$. [CrossRef] [PubMed]

48. Shilov, A.E.; Shul'pin, G.B. Activation and Catalytic Reactions of Saturated Hydrocarbons in the Presence of Metal Complexes; Kluwer Academic Publishers: Dordrecht, The Netherlands; Boston, MA, USA; London, UK, 2000.

49. Schröder, K.; Junge, K.; Bitterlich, B.; Beller, M. Fe-catalyzed Oxidation Reactions of Olefins, Alkanes and Alcohols: Involvement of Oxo- and Peroxo Complexes. Top. Organomet. Chem. 2011, 33, 83-109.

50. Kirillov, A.M.; Shul'pin, G.B. Pyrazinecarboxylic acid and analogs: Highly efficient co-catalysts in the metal-complex-catalyzed oxidation of organic compounds. Coord. Chem. Rev. 2013, 257, 732-754. [CrossRef]

51. Sorokin, A.B. Phthalocyanine Metal Complexes in Catalysis. Chem. Rev. 2013, 113, 8152-8191. [CrossRef] [PubMed]

52. Martins, L.M.D.R.S.; Pombeiro, A.J.L. Tris(pyrazol-1-yl)methane metal complexes for catalytic mild oxidative functionalizations of alkanes, alkenes and ketones. Coord. Chem. Rev. 2014, 265, 74-88. [CrossRef]

53. Afanasiev, P.; Sorokin, A.B. $\mu$-Nitrido Diiron Macrocyclic Platform: Particular Structure for Particular Catalysis. Acc. Chem. Res. 2016, 49, 583-593. [CrossRef] [PubMed] 
54. Blomberg, M.R.A.; Borowski, T.; Himo, F.; Liao, R.-Z.; Siegbahn, P.E.M. Quantum Chemical Studies of Mechanisms for Metalloenzymes. Chem. Rev. 2014, 114, 3601-3658. [CrossRef] [PubMed]

55. Poulos, T.L. Heme Enzyme Structure and Function. Chem. Rev. 2014, 114, 3919-3962. [CrossRef] [PubMed]

56. Trehoux, A.; Mahy, J.-P.; Avenier, F. A growing family of $\mathrm{O}_{2}$ activating dinuclear iron enzymes with key catalytic diiron(III)-peroxo intermediates: Biological systems and chemical models. Coord. Chem. Rev. 2016, 322, 142-158. [CrossRef]

57. Shul'pin, G.B. Selectivity in C-H Functionalizations. In Comprehensive Inorganic Chemistry II, 2nd ed.; Reedijk, J., Poeppelmeier, K., Casella, L., Eds.; Elsevier: Amsterdam, The Netherlands, 2013; Volume 6; pp. 79-104.

58. Bilyachenko, A.N.; Levitsky, M.M.; Yalymov, A.I.; Korlyukov, A.A.; Khrustalev, V.N.; Vologzhanina, A.V.; Shul'pina, L.S.; Ikonnikov, N.S.; Trigub, A.E.; Dorovatovskii, P.V.; et al. Cage-like Fe,Na-Germsesquioxanes: Structure, Magnetism, and Catalytic Activity. Angew. Chem. Int. Ed. 2016, 55, 15360-15363. [CrossRef] [PubMed]

59. Shul'pin, G.B. C-H functionalization: Thoroughly tuning ligands at a metal ion, a chemist can greatly enhance catalyst's activity and selectivity, Perspective. Dalton Trans. 2013, 42, 12794-12818. [CrossRef]

60. Shul'pin, G.B. Selectivity enhancement in functionalization of C-H bonds: A review. Org. Biomol. Chem. 2010, 8, 4217-4228. [CrossRef] [PubMed]

61. Shul'pin, G.B.; Druzhinina, A.N. Hydroperoxidation of alkanes by atmospheric oxygen in the presence of hydroquinone or quinone catalyzed by copper(II) acetate under visible light irradiation. React. Kinet. Catal. Lett. 1992, 47, 207-211. [CrossRef]

62. Shul'pin, G.B. Metal-catalyzed hydrocarbon oxygenations in solutions: The dramatic role of additives: A review. J. Mol. Catal. A Chem. 2002, 189, 39-66. [CrossRef]

63. Shul'pin, G.B. Metal-catalysed hydrocarbon oxidations. C. R. Chim. 2003, 6, 163-178. [CrossRef]

64. Shul'pin, G.B. Hydrocarbon Oxygenations with Peroxides Catalyzed by Metal Compounds. Mini Rev. Org. Chem. 2009, 6, 95-104. [CrossRef]

65. Shul'pin, G.B.; Kozlov, Y.N.; Shul'pina, L.S.; Kudinov, A.R.; Mandelli, D. Extremely Efficient Alkane Oxidation by a New Catalytic Reagent $\mathrm{H}_{2} \mathrm{O}_{2} / \mathrm{Os}_{3}(\mathrm{CO})_{12}$ /Pyridine. Inorg. Chem. 2009, 48, 10480-10482. [CrossRef] [PubMed]

66. Shul'pin, G.B.; Kozlov, Y.N.; Shul'pina, L.S.; Petrovskiy, P.V. Oxidation of alkanes and alcohols with hydrogen peroxide catalyzed by complex $\mathrm{Os}_{3}(\mathrm{CO})_{10}(\mathrm{mu}-\mathrm{H})_{2}$. Appl. Organomet. Chem. 2010, 24, 464-472.

67. Olivo, G.; Lanzalunga, O.; Di Stefano, S. Non-Heme Imine-Based Iron Complexes as Catalysts for Oxidative Processes. Adv. Synth. Catal. 2016, 358, 843-863. [CrossRef]

68. Garcia-Bosch, I.; Siegel, M.A. Copper-Catalyzed Oxidation of Alkanes with $\mathrm{H}_{2} \mathrm{O}_{2}$ under a Fenton-like Regime. Angew. Chem. Int. Ed. 2016, 128, 13065-13068. [CrossRef]

69. Shul'pin, G.B.; Kozlov, Y.N.; Nizova, G.V.; Süss-Fink, G.; Stanislas, S.; Kitaygorodskiy, A.; Kulikova, V.S. Oxidations by the reagent " $\mathrm{O}_{2}-\mathrm{H}_{2} \mathrm{O}_{2}$-vanadium derivative-pyrazine-2-carboxylic acid". Part 12. Main features, kinetics and mechanism of alkane hydroperoxidation. J. Chem. Soc. Perkin Trans. 2001, 2, 1351-1371. [CrossRef]

70. Kozlov, Y.N.; Romakh, V.B.; Kitaygorodskiy, A.; Buglyó, P.; Süss-Fink, G.; Shul'pin, G.B. Oxidation of 2-Propanol and Cyclohexane by the Reagent "Hydrogen Peroxide-Vanadate Anion-Pyrazine-2-carboxylic Acid": Kinetics and Mechanism. J. Phys. Chem. A 2007, 111, 7736-7752. [CrossRef] [PubMed]

71. Shul'pin, G.B.; Kozlov, Y.N.; Shul'pina, L.S.; Carvalho, W.; Mandelli, D. Oxidation reactions catalyzed by osmium compounds. Part 4. Highly efficient oxidation of hydrocarbons and alcohols including glycerol by the $\mathrm{H}_{2} \mathrm{O}_{2} / \mathrm{Os}_{3}(\mathrm{CO})_{12} /$ pyridine reagent. RSC Adv. 2013, 3, 15065-15074. [CrossRef]

72. Vinogradov, M.M.; Shul'pina, L.S.; Kozlov, Y.N.; Kudinov, A.R.; Ikonnikov, N.S.; Shul'pin, G.B. Oxidation of hydrocarbons and alcohols with peroxides catalyzed by new pi-cymene osmium complexes. J. Organometal. Chem. 2015, 784, 52-61. [CrossRef]

73. Shul'pina, L.S.; Kudinov, A.R.; Mandelli, D.; Carvalho, W.A.; Kozlov, Y.N.; Vinogradov, M.M.; Ikonnikov, N.S.; Shul'pin, G.B. Oxidation of alkanes and benzene with hydrogen peroxide catalyzed by ferrocene in the presence of acids. J. Organometal. Chem. 2015, 793, 217-231. [CrossRef]

74. Gryca, I.; Machura, B.; Małecki, J.G.; Kusz, J.; Shul'pina, L.S.; Ikonnikov, N.S.; Shul'pin, G.B. p-Tolylimido rhenium(V) complexes with phenolate-based ligands: Synthesis, X-ray studies and catalytic activity in oxidation with tert-butylhydroperoxide. Dalton Trans. 2016, 45, 334-351. [CrossRef] [PubMed] 
75. Gryca, I.; Machura, B.; Shul'pina, L.S.; Shul'pin, G.B. Synthesis, structures and catalytic activity of p-tolylimido rhenium(V) complexes incorporating quinoline-derived ligands. Inorg. Chim. Acta 2017, 455, 683-695. [CrossRef]

76. Bilyachenko, A.N.; Kulakova, A.N.; Levitsky, M.M.; Petrov, A.A.; Korlyukov, A.A.; Shul'pina, L.S.; Khrustalev, V.N.; Dorovatovskii, P.V.; Vologzhanina, A.V.; Tsareva, U.S.; et al. Unusual Tri-, Hexa-, and Nonanuclear $\mathrm{Cu}$ (II) Cage Methylsilsesquioxanes: Synthesis, Structures, and Catalytic Activity in Oxidations with Peroxides. Inorg. Chem. 2017, 56. 